\title{
Clinical and functional impact of TARBP2 over-expression in adrenocortical carcinoma
}

\author{
Stefano Caramuta, ${ }^{1,3}$, Linkiat Lee ${ }^{1,3}$, Deniz M Özata ${ }^{1,3}$, Pinar Akçakaya ${ }^{1,3}$, Hong Xie ${ }^{1,3}$, \\ Anders Höög $^{3}$, Jan Zedenius ${ }^{2,4}$, Martin Bäckdahl ${ }^{2,4}$, Catharina Larsson ${ }^{1,3}$ \\ and Weng-Onn Lui ${ }^{1,3}$ \\ Departments of ${ }^{1}$ Oncology-Pathology ${ }^{2}$ Molecular Medicine and Surgery, Karolinska Institutet, Stockholm, Sweden \\ ${ }^{3}$ Cancer Center Karolinska (CCK), R8:04, Karolinska University Hospital-Solna, SE-17176 Stockholm, Sweden \\ ${ }^{4}$ Department of Breast and Endocrine Surgery, Karolinska University Hospital, Stockholm, Sweden
}

Correspondence should be addressed to S Caramuta or W-O Lui Email

stefano.caramuta@ki.se or weng-onn.lui@ki.se

\begin{abstract}
Deregulation of microRNA (miRNA) expression in adrenocortical carcinomas (ACCs) has been documented to have diagnostic, prognostic, as well as functional implications. Here, we evaluated the mRNA expression of DROSHA, DGCR8, DICER (DICER1), TARBP2, and PRKRA, the core components in the miRNA biogenesis pathway, in a cohort of 73 adrenocortical tumors (including 43 adenomas and 30 carcinomas) and nine normal adrenal cortices using a RT-qPCR approach. Our results show a significant over-expression of TARBP2, DICER, and $D R O S H A$ in the carcinomas compared with adenomas or adrenal cortices $(P<0.001$ for all comparisons). Using western blot and immunohistochemistry analyses, we confirmed the higher expression of TARBP2, DICER, and DROSHA at the protein level in carcinoma cases. Furthermore, we demonstrate that mRNA expression of TARBP2, but not DICER or DROSHA, is a strong molecular predictor to discriminate between adenomas and carcinomas.

Functionally, we showed that inhibition of TARBP2 expression in human NCI-H295R ACC cells resulted in a decreased cell proliferation and induction of apoptosis. TARBP2 over-expression was not related to gene mutations; however, copy number gain of the TARBP2 gene was observed in $57 \%$ of the carcinomas analyzed. In addition, we identified that miR-195 and miR-497 could directly regulate TARBP2 and DICER expression in ACC cells. This is the first study to demonstrate the deregulation of miRNA-processing factors in adrenocortical tumors and to show the clinical and biological impact of TARBP2 over-expression in this tumor type.
\end{abstract}
Key Words
- TARBP2
over-expression
- adrenocortical cancer
- diagnostic
- function

Endocrine-Related Cancer (2013) 20, 551-564

\section{Introduction}

Adrenocortical tumors are detected in up to $7 \%$ of the population and are often found as incidental tumors (Hammarstedt et al. 2010). The majority of these tumors are adenomas while only a small proportion are classified as adrenocortical carcinomas (ACCs) with an annual incidence of two cases per million among adults worldwide (Schteingart 2007).

The prognosis for ACCs is poor with reported 5-year survival rates between 20 and $45 \%$, and treatment alternatives are very limited (Allolio \& Fassnacht 2006, 
Bertherat et al. 2006). In addition, discrimination of ACCs from adrenocortical adenomas can be challenging. Generally, a tumor is unambiguously classified as ACC when it presents signs of invasion and/or distant metastases. In the absence of metastasis, the diagnosis relies on the histopathological evaluation, and the histological Weiss score classification is still the most commonly used one (Weiss et al. 1989). Given the limitation of conventional histopathology in adrenocortical tumor diagnostics, the identification of additional molecular markers with diagnostic and prognostic potential for clinical management of ACC is needed.

Previous reports identified over-expression of IGF2, loss-of-heterozygosity at $11 \mathrm{p} 15$ and $17 \mathrm{p} 13$, and increased MIB-1 proliferation index as molecular biomarkers to distinguish adrenocortical adenomas and carcinomas (Yano et al. 1989, Ilvesmaki et al. 1993, Gicquel et al. 1994, Stojadinovic et al. 2003). Several studies have shown the potential of mRNA and microRNA (miRNA) profiling to correctly classify adenomas or carcinomas and to identify subgroups of ACC patients with different survival and outcome (de Fraipont et al. 2005, Giordano et al. 2009, Laurell et al. 2009, de Reynies et al. 2009, Soon et al. 2009, Tombol et al. 2009, Özata et al. 2011, Patterson et al. 2011, Schmitz et al. 2011).

While the role of miRNAs in cancer development and progression is established, recent studies are also focusing on the deregulation of miRNA-processing factors, which are needed for miRNA maturation. This pathway has been shown to play an important role in tumor initiation and progression and to have a prognostic potential in several cancer types (Roh et al. 2005, Sugito et al. 2006, Chiosea et al. 2007, Merritt et al. 2008, Melo et al. 2009).

In this study, we evaluated the expression of the miRNA machinery components as potential diagnostic and prognostic markers in adrenocortical tumors. We further investigated the effect of TARBP2 deregulation on cell growth and apoptosis and explored possible mechanisms responsible for its deregulation in this tumor type.

\section{Materials and methods}

\section{Clinical material}

This study included 73 snap-frozen primary sporadic adrenocortical tumors from 72 patients and nine histopathologically verified normal adrenal cortices. All tissue samples were stored at $-80^{\circ} \mathrm{C}$ until use. Representative sections from all specimens were subjected to histopathological evaluation to confirm more than $80 \%$ tumor cells in the samples. Tumors were histopathologically classified according to the WHO classification (DeLellis et al. 2004). The diagnosis of ACC was based on vascular invasion, nuclear grade, mitotic index, tumor necrosis, invasion of surrounding organs, and/or presence of distant metastasis. Clinical details of tumor cases have been partially published in previous studies (Laurell et al. 2009, Özata et al. 2011) and are summarized in Table 1 . All samples were collected with informed consent, and the study of tissue material was approved by the local ethics committee (Dnr 01-353,01-136).

\section{Cell line}

The ACC cell line NCI-H295R was purchased from the American Type Culture Collection (LGC Standards, Middlesex, UK) and maintained in culture as described previously (Özata et al. 2011). Authentication of the cell line was verified by short tandem repeat profiling, as described in our recent study (Özata et al. 2011).

Table 1 Clinical features for the adrenocortical tumor cases studied.

\begin{tabular}{|c|c|c|}
\hline Clinical features & Adenomas & Carcinomas \\
\hline No. of cases & 43 & 29 \\
\hline \multicolumn{3}{|l|}{ Gender } \\
\hline Male & 12 & 13 \\
\hline Female & 31 & 16 \\
\hline \multicolumn{3}{|l|}{ Age (years) } \\
\hline Median & 55 & 61 \\
\hline Min-max & $16-81$ & $28-84$ \\
\hline \multicolumn{3}{|l|}{ Subtypes } \\
\hline Cushing & 13 & NA \\
\hline Aldosteronoma & 16 & NA \\
\hline Non-hyperfunctioning & 14 & NA \\
\hline \multicolumn{3}{|l|}{ Tumor size $(\mathrm{cm})^{\mathrm{a}}$} \\
\hline Median & 3.5 & 12 \\
\hline Min-max & $0.9-6.5$ & $7-21$ \\
\hline \multicolumn{3}{|l|}{ Metastasis } \\
\hline Yes & 0 & 16 \\
\hline No & 43 & 13 \\
\hline \multicolumn{3}{|l|}{ Follow-up (months) } \\
\hline Median & 39 & 42 \\
\hline Min-max & $12-258$ & 2-195 \\
\hline \multicolumn{3}{|l|}{ Follow-up (outcome) } \\
\hline Alive & 38 & 13 \\
\hline Dead of other causes ${ }^{b}$ & 5 & 4 \\
\hline DOD & 0 & 12 \\
\hline
\end{tabular}

NA, not available; DOD, dead of disease.

${ }^{a}$ No information was available for one of the carcinomas.

${ }^{b}$ Patients who died for causes not related to the disease.

Published by Bioscientifica Ltd. 


\section{DNA and RNA extraction}

Genomic DNA was extracted using DNeasy Blood and Tissue Kit (Qiagen) and total RNA was isolated using mirVana miRNA Isolation Kit (Applied Biosystems/Ambion, Austin, TX, USA). Quantification of isolated DNA or RNA was performed by NanoDrop ND-1000 spectrophotometer (NanoDrop Technologies, Wilmington, DE, USA).

\section{RT quantitative real-time PCR (RT-qPCR) analysis}

cDNA was synthesized from $100 \mathrm{ng}$ of total RNA using High Capacity cDNA RT Kit (Applied Biosystems), and the mRNA expression was quantified for DICER (DICER1) (ID_00998578_m1),DROSHA (ID_01095029_m1), TARBP2 (ID_00998379_m1), DGCR8 (ID_00987089_m1), PRKRA (ID_00269379_m1), IGF2 (ID_00277496_s1), and H19 (ID_00399293_g1) using a 7900HT Real-Time PCR System (Applied Biosystems). Expression of $18 \mathrm{~S}$ rRNA (ID_99999901_s1) was evaluated in parallel for normalization purpose. $18 S$ was chosen as a reference gene for its stable expression in all samples (Supplementary Figure S1, see section on supplementary data given at the end of this article). Expression levels of miR-497 (ID_001043) and miR-195 (ID_000494) were quantified in the NCI-H295R cells after transfection experiments to evaluate transfection efficiency. The expression of these two miRNAs has previously been evaluated in a subset of the adrenocortical tumors (Özata et al. 2011). Here, we analyzed the levels of miR-195 and miR-497 in additional five ACC cases included in this study. Normalization for miRNA expression was done using RNU6B (RNU6-6P) (ID_001093). All reactions were performed in triplicate, and relative expression levels were reported as $2^{-\Delta C T}$.

\section{Western blot analysis}

Whole cell lysates were prepared as described previously (Özata et al. 2011) for detection of miRNA machinery proteins using primary antibody anti-TARBP2 (sc-100909; Santa Cruz Biotechnology, Inc.) at 1:1000 dilution, antiDICER (ab14601; Abcam, Cambridge, UK) at 1:200 dilution, or anti-DROSHA (ab12286; Abcam) at 1:400 dilution. Anti-GAPDH antibody (sc-47724; Santa Cruz Biotechnology, Inc.) diluted at 1:5000 was used for normalization. Protein levels were quantified on X-ray films from immunoblots using ImageJ software (http://rsb.info.nih.gov/ij/).

\section{Immunohistochemistry}

Immunohistochemistry of TARBP2 was performed in 34 adrenocortical tumors (17 adenomas and 17 ACCs) and five normal adrenal tissues using anti-TARBP2 (ab72547, Abcam). The details are available in the Supplementary Materials and methods, see section on supplementary data given at the end of this article. The TARBP2 immunostaining and subcellular localization were evaluated by a pathologist (A $\mathrm{H}$ ). The cytoplasmic immunoreactivity was expressed in most tumor cells with the most obvious difference in the intensity of the immunoreactivity. Therefore, the clinical specimens were scored as having strong, moderate, or weak/negative TARBP2 immunoreactivity. The nuclear immunoreactivity, on the other hand, did not appear in all nuclei and the cases were classified as positive, mixed, or negative. In the adenomas, two different cell types were identified (oxyphilic and lipid-rich cells) and evaluated for both cytoplasmic and nuclear TARBP2 staining.

\section{Validation of potential molecular biomarkers in independent cohorts}

Expression data from two previously published microarray data sets were downloaded from ArrayExpress database. Giordano et al.'s study included a total of 55 adrenocortical tumors (22 adenomas and 33 carcinomas) and ten adrenal cortices (http://www.ebi.ac.uk/arrayexpress/ experiments/E-GEOD-10927), while 92 adrenocortical tumors (58 adenomas and 34 carcinomas) were analyzed in de Reynies et al.'s study (http://www.ebi.ac.uk/arrayexpress/experiments/E-TABM-311). Expression values for TARBP2 (HG-U133_Plus_2.0 probe set: 203677_s_at), DICER (213229_at, 206061_s_at), DROSHA (2218269_at), IGF2 (202409_at, 202410_x_at, 210881_s_at), and H19 (224646_x_at, 224997_x_at) were extracted from the microarray data. Geometrical mean was used to obtain a single expression value for genes that were represented by more than one probe set on the Affymetrix chip. Comparison of mRNA expression among sample groups for each gene and evaluation of their predictive value in ACC classification was performed as described in the 'Statistical analyses' section.

\section{Transfection experiments in $\mathrm{NCl}-\mathrm{H} 295 \mathrm{R}$ cells}

NCI-H295R cells were transfected using Amaxa Nucleofector technology (Lonza, Basel, Switzerland) with pre-miR-195, pre-miR-497 (PM10827 and PM10490 respectively; Applied Biosystems/Ambion), or siTARBP2 (sc-106846; Santa Cruz Biotechnology, Inc.), as described previously (Özata et al. 2011). Pre-miR Negative control\#1 (4464058; Applied Biosystems/Ambion) or siCTR (sc-36869; Santa Cruz Biotechnology, Inc.) were used as

Published by Bioscientifica Ltd. 
negative controls. All transfection experiments were repeated at least three times.

\section{WST-1 colorimetric assay}

Cell viability was evaluated using WST-1 colorimetric assay (Roche Applied Science), as described previously (Özata et al. 2011). All experiments were conducted in eight wells for each condition and replicated at least three times independently. Cell viability was calculated by comparing the absorbance values of the samples after background subtraction and normalized to the siCTR-treated cells.

\section{Apoptosis caspase-3 colorimetric assay}

After $72 \mathrm{~h}$ of transfection, the effect on apoptosis was evaluated using caspase- 3 colorimetric assay (Genscript, Piscataway, NJ, USA), as described previously (Özata et al. 2011). Relative caspase-3 activity was calculated by comparing the absorbance values of the siTARBP2-treated cells with the respective siCTR-treated cells. All experiments were replicated three times.

\section{Mutation analysis}

All coding exons and flanking exon-intron junctions of the TARBP2 gene (NM_134323) were sequenced in 23 ACC specimens. The PCR products were purified using ExoSAPIT (USB Corporation/Affymetrix, Cleveland, OH, USA) and sequenced at the KIGene facility. Primer sequences and PCR conditions used for the analysis are detailed in Supplementary Table S1, see section on supplementary data given at the end of this article.

\section{TaqMan copy number assay}

TaqMan copy number assay (Applied Biosystems) was used to evaluate the changes of TARBP2 copy number in adrenal cortices and adrenocortical tumors. The target gene TARBP2 (ID_02091089_cn) and the reference gene RNaseP (ID_4403326) were analyzed in parallel. The calculated relative copy numbers and the predicted copy numbers were estimated using CopyCaller software (Applied Biosystems). DNA from normal adrenal cortex was used as calibrator for the analysis. All reactions were performed in triplicate.

\section{Argonaute 2 co-immunoprecipitation and analysis of argonaute 2-associated mRNAs}

Cells $\left(2 \times 10^{6}\right.$ cells/dish) were transfected with pre-miR Negative control\#1, pre-miR-195 or pre-miR-497, and seeded in six tissue culture plates $(10 \mathrm{~cm})$. After $72 \mathrm{~h}$ of transfection, the cells were used for co-immunoprecipitation (co-IP) experiments using protein G Sepharose 4 Fast Flow beads (17-0618-01; GE Healthcare, Uppsala, Sweden) coated with mouse anti-human argonaute 2 (Ago2) antibody (ab57113; Abcam), as described previously (Xie et al. 2012). Ago2-bound RNA was extracted with TRIzol reagent (Invitrogen). DICER and TARBP2 mRNA expression levels were measured by RT-qPCR and normalized to $m i R-483-3 p$ for input and IP samples. This miRNA was chosen as an internal control due to its high abundance in the NCI-H295R cells. Enrichment of DICER and TARBP2 mRNAs bound to Ago2 was calculated from the relative amount of mRNA detected in IP samples divided by the relative amount of mRNA in the corresponding input samples.

\section{Statistical analyses}

Statistica 8.0 (StatSoft, Inc., Tulsa, OK, USA) or MS Office Excel was used for statistical calculations. One-way ANOVA and unpaired Student's t-test were used to compare mRNA and protein expression levels among or between sample groups, and paired Student's $t$-test was performed to analyze transfection and Ago2-IP experiments. The patient population was divided into two groups based on high or low expression of DICER, DROSHA, TARBP2, IGF2, or H19 according to the median expression levels among the adrenocortical tumors. Correlations between TARBP2, DICER, and DROSHA mRNA and protein expression levels were assessed by Pearson's correlation analyses and $P$ values were estimated by permuting the samples 1000 times. The association between mRNA gene expression levels and clinicalhistopathological parameters was analyzed using $\chi^{2}$ test. Kaplan-Meier analysis was carried out to obtain survival curves. The survival curves of different patient groups were compared using log-rank test. Overall survival was the period from the time of diagnosis until the end of followup or death of the patient. For overall survival analysis, survival was censored if patients were still alive at the end of the follow-up. Disease-free survival was the time between the initial diagnosis and the end of follow-up or documented recurrence/death. For disease-free survival analysis, the data were censored if patients did not show any recurrence or died for other causes not related to disease. In the survival analyses, the recurrent ACC (Ca30) was not included. All the analyses were two tailed and $P$ values $<0.05$ were considered significant.

Published by Bioscientifica Ltd. 


\section{Results}

\section{Deregulation of miRNA-processing factors in adrenocortical tumors and clinical associations}

We analyzed the mRNA expression levels of five miRNA-processing genes (DROSHA, DGCR8, DICER, TARBP2, and PRKRA) in 73 adrenocortical tumors and nine adrenal cortices using RT-qPCR. In comparison to adrenal cortices, 29 of 30 ACCs (96\%) showed a significantly increased expression of TARBP2 $(P=0.0001)$. Twenty-six carcinomas $(87 \%)$ also exhibited significant over-expression of DICER $(P=0.024)$ and 24 $(80 \%)$ of the carcinomas presented a significantly increased DROSHA expression $(P=0.03)$ (Fig. 1A). By contrast, abnormal mRNA expression of TARBP2, DICER, and DROSHA was less frequent in adenomas (TARBP2, 32\% (14/43); DICER, 37\% (16/43); and DROSHA, 40\% (17/43)) (Fig. 1A). Significant over-expression of TARBP2 (1.3- to 4-fold, $P<0.0001)$, DICER (0.4- to 5-fold, $P<0.0001$ ), and DROSHA (0.2- to 4.5 -fold, $P<0.0001$ ) was also observed in carcinomas when compared with adenomas (Fig. 1A). However, we did not observe any significant differences for DGCR8 or PRKRA between the three sample groups (Supplementary Figure S2, see section on supplementary data given at the end of this article).

The adenoma samples included in the study consisted of 13 Cushing, 16 aldosteronoma, and 14 non-hyperfunctional tumor samples. Comparing the mRNA expression levels of the five miRNA machinery genes analyzed, we did not detect any significant differences between the three adenoma subgroups (Supplementary Figure S3). Moreover, for carcinoma cases, we did not observe any significant association between DROSHA, DGCR8, DICER, TARBP2, or PRKRA mRNA levels and clinical-histopathological parameters such as gender, age, tumor size, or presence of metastasis (data not shown).

To establish whether the increased mRNA expressions were reflected on the protein level, TARBP2, DICER, and DROSHA were examined by western blot analysis in a subset of nine adrenal cortices, 23 adenomas, and 19 carcinomas. Concordantly with gene expression results, carcinoma cases showed a significant increased expression of the three proteins analyzed when compared with adenomas and adrenal cortices $(P<0.01$ for all comparisons) (Fig. 1B and Supplementary Figure S4, S5, and S6). In addition, Pearson's correlation analysis showed a significant correlation between western blot and RT-qPCR results for TARBP2 (Cor $=0.75, P<0.001)$, DICER (Cor $=0.67$, $P<0.001)$, and DROSHA (Cor $=0.5, P<0.01)$ (Fig. 1C).
Sixteen of the ACC cases included in the study were diagnosed with distant metastases (seven at time of diagnosis and nine during follow-up). Among the ACCs, univariate analysis identified presence of distant metastasis as a predictive factor of shorter overall survival (log-rank, $P=0.014$ ) and disease-free survival (log-rank, $P=0.001$ ) (Supplementary Figure S7). However, we did not find any significant association between size, gender, age, or expression levels of miRNA-processing factors with survival among the ACC patients (data not shown).

\section{Immunohistochemical analysis of TARBP2 expression}

Based on the RT-qPCR and western blot analyses, TARBP2 showed the strongest upregulation in ACC. To further confirm this over-expression, we evaluated the protein level of TARBP2 in a subset of adrenocortical tumors (17 adenomas and 17 carcinomas) and five normal adrenal glands using immunohistochemistry. The immunostaining results are summarized in Supplementary Table S2 and exemplified in Fig. 2.

RNA interference (RNAi) activity mainly occurs in the cytoplasm, and the essential RNAi-processing factors, such as DICER, TARBP2, and argonautes, are usually localized in the cytoplasm (Chendrimada et al. 2005). Interestingly, Kim et al. (2006) reported that TARBP2 is required for siRNA-mediated transcriptional silencing in human cells, suggesting its role in the nuclear compartment. We therefore sought to determine subcellular localization and expression of TARBP2 in adrenocortical tumors. Our results showed that TARBP2 was mainly expressed in the cytoplasm, although a weaker nuclear staining was also observed. In the normal adrenal tissues, positive cytoplasmic staining for TARBP2 was present in cells of the zona glomerulosa while cells of zona fasciculata and reticularis showed weak/negative cytoplasmic staining (Fig. 2A). In the adenomas, TARBP2 staining was mainly confined to oxyphilic cells while the preponderance of lipid-rich cells was negative for TARBP2 immunoreactivity. Twelve of the 17 adenomas (70\%) showed a moderate cytoplasmic staining, four cases (24\%) demonstrated weak or negative TARBP2 expression while only one case presented strong TARBP2 immunoreactivity (Fig. 2B and Supplementary Table S2). Concordantly with the results obtained by RT-qPCR and western blot, most of the ACCs $(14 / 17,82 \%)$ showed strong cytoplasmic TARBP2 staining in nearly all tumor cells, while moderate TARBP2 expression was detected in only three ACCs (18\%) (Fig. 2C and Supplementary Table S2).

Published by Bioscientifica Ltd. 
A



B
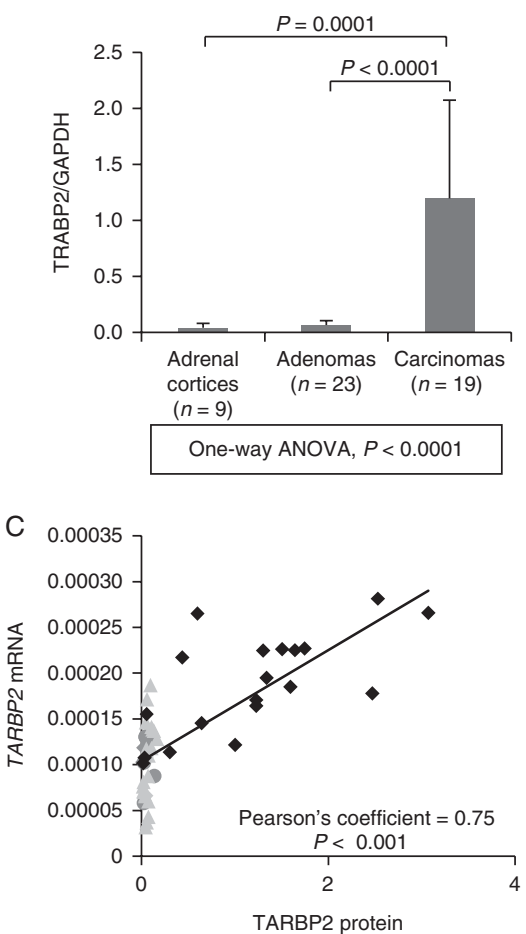
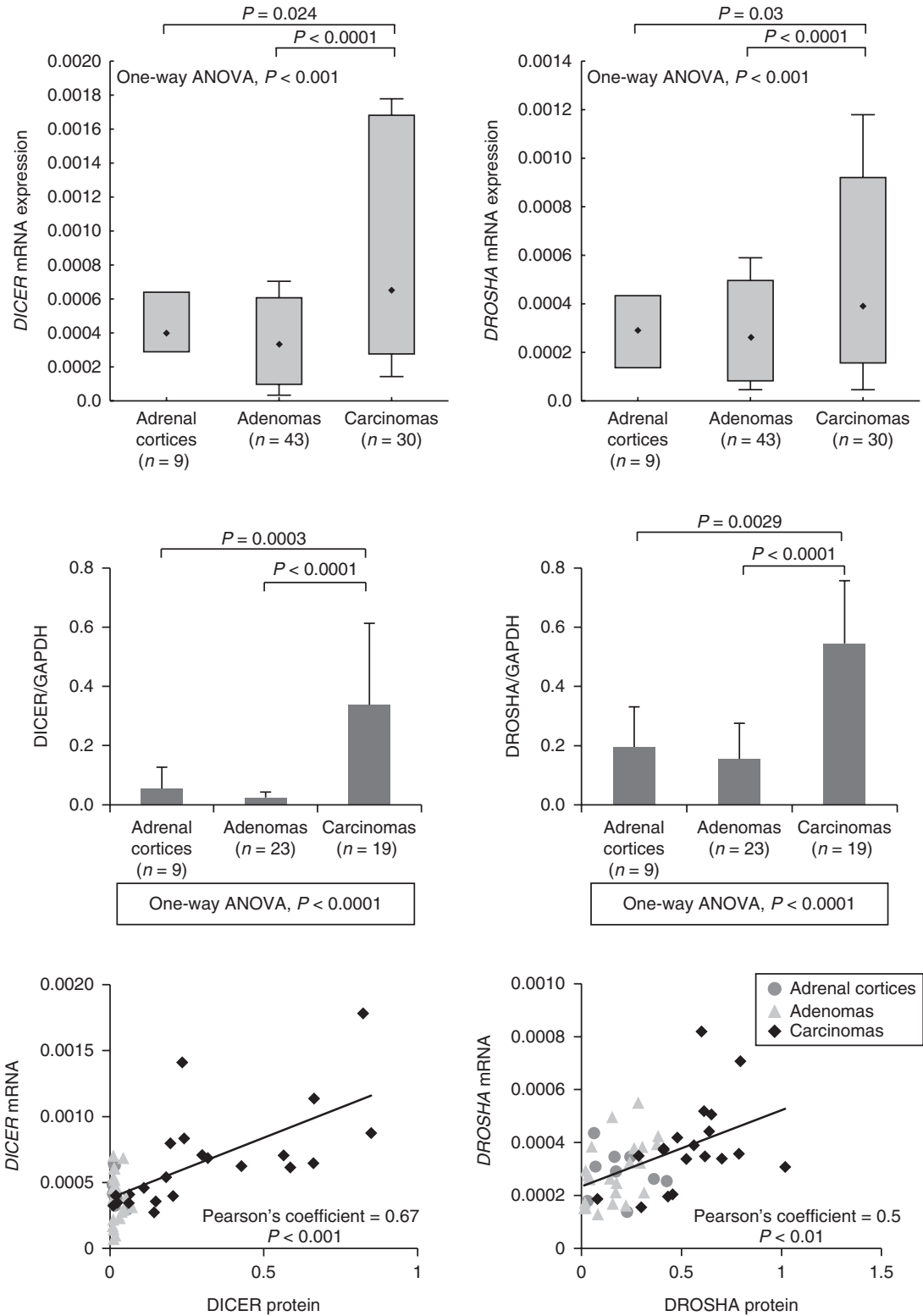

One-way ANOVA, $P<0.0001$

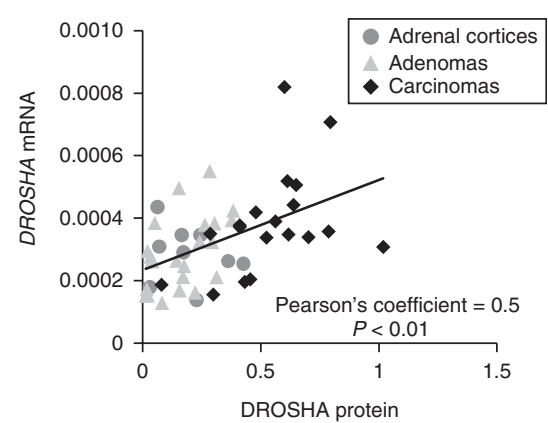

Figure 1

Relative expression levels of miRNA-processing machinery components in adrenocortical tumors and adrenal cortices. (A) Box plots show relative mRNA expression levels for TARBP2, DICER, and DROSHA in nine normal adrenal cortices, 43 adenomas, and 30 carcinomas measured by RT-qPCR. 185 was used as a reference gene. The expression levels of mRNA between groups were compared using one-way ANOVA models and $P<0.05$ was

At nuclear level, among the five normal adrenal cortices, only a single case showed a mixed nuclear staining in the cells of the zona glomerulosa, while all the other samples exhibited negative TARBP2 nuclear immunoreactivity. Among the adenomas, most of the cases (12/17) presented mixed or positive nuclear TARBP2 expression in oxyphilic cells while the remaining five cases considered significant. (B) Comparison of TARBP2, DICER, and DROSHA protein expression levels among different groups. GAPDH was used for normalization. $P$ values were calculated using one-way ANOVA models and $P<0.05$ was considered significant. (C) Scatter plots showing correlation between mRNA and protein levels for TARBP2, DICER, and DROSHA as assessed by Pearson's correlation analysis.

showed negative staining in the nuclei of the same cell type. On the other hand, lipid-rich cells had mixed or positive nuclear staining in five adenomas and negative in 12 adenomas. The majority of ACC tumor cells were positive for TARBP2 nuclear expression (10/17), while five showed mixed nuclear staining and two cases were negative (Fig. 2 and Supplementary Table S2). However,

Published by Bioscientifica Ltd. 
A

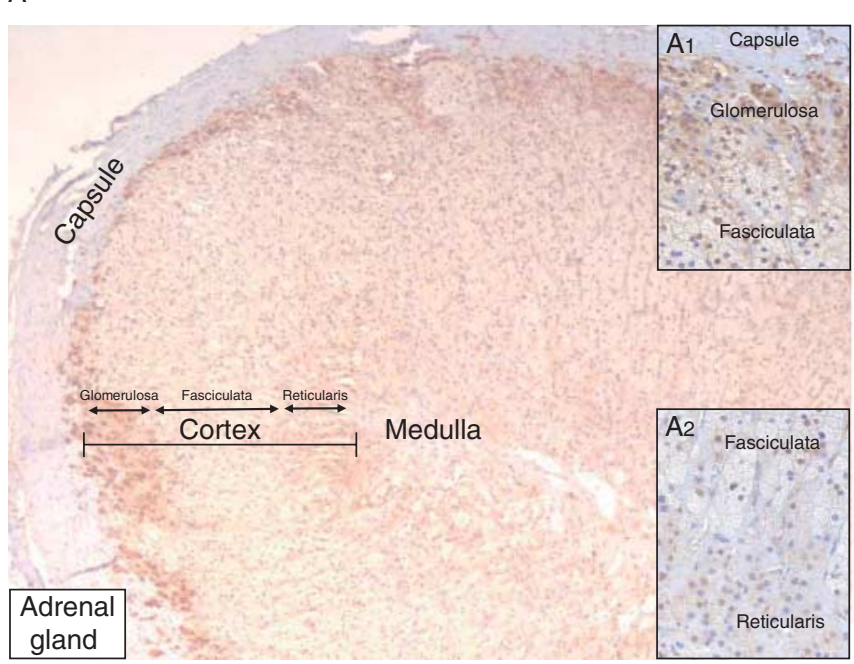

B
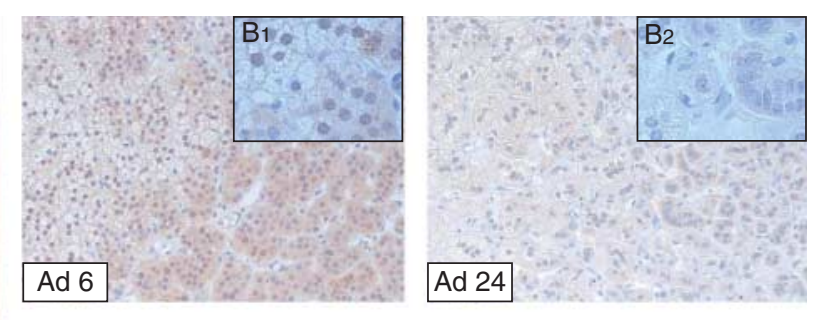

C
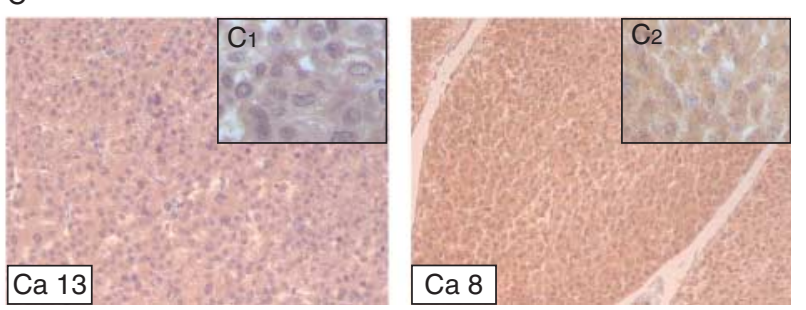

\section{Figure 2}

Immunohistochemical detection of TARBP2 expression in normal adrenal glands $(A, \times 40)$, adrenocortical adenomas $(B, \times 160)$, and adrenocortical carcinomas $(C, \times 160)$. (A) In the normal adrenal gland, TARBP2 staining is mainly present in the zona glomerulosa and, at lower intensity, in the zona fasciculata and reticularis (inserts $A_{1}$ and $A_{2}, \times 160$ ). (B) The adenomas show a moderate (insert $B_{1}, \times 400$ ) or weak/negative (insert $B_{2}, \times 400$ ) TARBP2 expression in the cytoplasm of oxyphilic cells while lipid-rich cells

positive, mixed, or negative TARBP2 nuclear expression did not show any significant correlation with histopathological parameters and survival among the ACC cases (data not shown).

\section{TARBP2 as a novel molecular predictor of carcinoma}

Given the observed over-expression of TARBP2, DICER, and DROSHA in ACCs, we sought to investigate whether the ACCs could be accurately classified based on the expression levels of these three genes. Adrenocortical tumor patients were divided into high or low mRNA levels of TARBP2, DICER, and DROSHA according to their median expression levels. Among the three genes analyzed, TARBP2 showed the highest sensitivity and specificity to discriminate between ACCs and adenomas. Twenty-seven patients with ACCs were correctly predicted based on the expression of TARBP2 mRNA (27/29 patients, 93\% sensitivity); however, 10/43 adenoma cases were misclassified, leading to a specificity of $76 \%$. Classification of ACCs based on DICER or DROSHA expression levels resulted in a much lower sensitivity and specificity (76 and $67 \%$ respectively).

Previous studies have clearly shown over-expression of IGF2 (Gicquel et al. 2001, Giordano et al. 2009, Laurell et al. 2009) or decreased expression of $H 19$ (Gao et al. 2002, only demonstrate weak/negative cytoplasmic TARBP2 staining. Most of the adenomas showed positive or mixed nuclear TARBP2 immunoreactivity among the oxyphilic cells and negative TARBP2 expression in the nuclei of lipid-rich cells. (C) The majority of carcinomas show a strong TARBP2 expression in the cytoplasm and mainly positive (insert $C_{1}, \times 400$ ) or mixed (insert $C_{2}, \times 400$ ) nuclear staining.

Giordano et al. 2009) in ACCs and demonstrated the potential of IGF2 as a biomarker for ACC diagnosis (Gicquel et al. 2001). We therefore compared the predictive values of IGF2, H19, TARBP2, DICER, and DROSHA for detection of ACC. As shown in Supplementary Table S3, see section on supplementary data given at the end of this article, the classification based on $H 19$ and TARBP2 expression had similar levels of sensitivity (SEN $=93 \%$ for both $H 19$ and TARBP2) and specificity ( $\mathrm{SPE}=79 \%$ for both $H 19$ and TARBP2), while IGF2 showed a slightly lower sensitivity (89\%) and specificity (77\%) when compared with TARBP2. The combination of TARBP2, IGF2, and H19 expressions had an additive effect in the predictive value for ACC $(\mathrm{SEN}=97 \%$ and $\mathrm{SPE}=81 \%)$. On the other hand, both DICER and DROSHA had lower prediction power than the three genes described earlier. The sensitivity, specificity, positive predictive value, negative predictive value, and overall accuracy for the five genes analyzed are summarized in Supplementary Table S3.

To further investigate the diagnostic power of TARBP2, DICER, and DROSHA in adrenocortical tumors and overcome limitations of pathological assessment, we applied disease-free survival as the end point for diagnosing ACC, which is similar to the approach applied by de Reynies et al. (2009). Among the 72 tumors analyzed,

Published by Bioscientifica Ltd 
TARBP2 mRNA expression was a good predictor of ACC (log-rank, $P<0.001$ ) and allowed an accurate classification of all seven cases with metastasis at the time of diagnosis. DROSHA could also significantly predict ACC cases (log-rank, $P=0.038$ ), although two carcinoma cases presenting metastasis at diagnosis were misclassified. However, DICER did not show any statistical significance (Supplementary Figure S8). We also tested the predictive potential for TARBP2 and DROSHA to detect ACCs among the 45 potentially malignant adrenocortical tumors after exclusion of tumors with sizes $\leq 3 \mathrm{~cm}$ and the seven patients presenting metastases at diagnosis. As shown by Kaplan-Meier analysis, TARBP2 was still found highly predictive of ACC among those without metastases at diagnosis (log-rank, $P=0.02$; Fig. 3) while DROSHA did not show any statistical significance (data not shown). The classification obtained according to TARBP2 expression was at least as accurate as the prediction based on IGF2 and H19 expressions or the combination of the three genes (Fig. 3).

\section{Validation in independent cohorts of adrenocortical tumors}

To strengthen our findings, we studied independent cohorts of 147 adrenocortical tumors and ten normal adrenal cortices from two previously published microarray data sets (Giordano et al. 2009, de Reynies et al. 2009). Concordantly with our results, TARBP2, DICER, and DROSHA were significantly over-expressed in carcinomas when compared with adenomas or normal adrenal cortices in both studies (Supplementary Figure S9, see section on supplementary data given at the end of this article). Moreover, in both cohorts, we confirmed the higher predictive values for TARBP2 when compared with DICER or DROSHA in the classification of ACC among adrenocortical tumors (Giordano et al.'s cohort: TARBP2, $\mathrm{SEN}=84 \%, \mathrm{SPE}=100 \%$; de Raynies et al.'s cohort: $T A R B P 2$, $\mathrm{SEN}=80 \%, \mathrm{SPE}=82 \%)$. As observed in our cohort, the combination of TARBP2, IGF2, and H19 could improve the overall prediction for ACC classification in both data sets (Supplementary Tables S4 and S5, see section on supplementary data given at the end of this article).

\section{TARBP2 affects cell viability and apoptosis in $\mathrm{NCl}-\mathrm{H} 295 \mathrm{R}$ cells}

The over-expression of TARBP2 observed in ACC tumors prompted us to investigate the functional consequences of TARBP2 alteration in human NCI-H295R ACC cells. Upon inhibition of TARBP2 expression, ACC cells showed a significant reduction of cell viability over time (Fig. 4A) and a markedly increase ( $\sim 30 \%)$ of cell death (Fig. $4 \mathrm{~B})$ in comparison with negative control cells.

\section{TARBP2 sequencing and copy number variations}

We investigated possible mechanisms that could induce over-expression of TARBP2 in ACCs. First, genomic DNA from 23 ACCs was screened for TARBP2 gene mutations by sequencing. However, no mutations were identified in any of the coding exons analyzed (data not shown).

As the TARBP2 gene is located in the chromosomal region $12 \mathrm{q} 13.13$ that is frequently gained/amplified in ACC (Stephan et al. 2008), we investigated TARBP2 gene copy number alterations in a subset of 28 carcinomas, 18 adenomas, and 3 normal adrenal cortices using TaqMan copy number assay. We observed copy number gain in 57\% of the carcinoma cases (16/28), but no changes among the adenomas and normal tissue samples (Supplementary Figure S10, see section on supplementary data given at the end of this article). However, the genomic copy number alteration did not always correspond with the TARBP2 mRNA levels. For examples, four tumors (Ca3, Ca20, Ca22, and Ca25), showing TARBP2 copy number gain, were among the cases with relatively low TARBP2 expression (Supplementary Figure S10). This discrepancy implies that additional mechanism(s), e.g. posttranscriptional regulation by miRNAs, may involve in TARBP2 regulation.

\section{miR-195 and $m i R-497$ regulate TARBP2 and DICER expression in adrenocortical tumors}

To explore a possible involvement of miRNAs in TARBP2 regulation, we first searched for the published underexpressed miRNAs in ACCs, thus showing an inverse expression pattern compared with TARBP2. We found 12 downregulated miRNAs that were reported in more than one study (Soon et al. 2009, Tombol et al. 2009, Özata et al. 2011, Patterson et al. 2011, Schmitz et al. 2011; Supplementary Table S6, see section on supplementary data given at the end of this article).

Next, we performed bioinformatic analysis using TargetScan (http://www.targetscan.org/) to identify whether any of the downregulated miRNAs have potential binding sites in the $3^{\prime}$-UTR of TARBP2. The analysis identified let-7 family members, miR-195 and miR-497, as possible regulators of TARBP2. In addition, potential target sites for these miRNAs were also present in the 3'-UTR of DICER (Fig. 5A). As let-7 family members were not significantly deregulated in ACCs compared with

Published by Bioscientifica Ltd. 



No at risk

adenomas

Predicted

carcinomas
$16 \begin{array}{lllllllllllllllll}15 & 10 & 8 & 7 & 7 & 7 & 7 & 6 & 6 & 6 & 5 & 5 & 5 & 3 & 2 & 2 & 2\end{array}$

$292521191613109076 \quad 5 \quad 5 \quad 5 \quad 5 \quad 4 \quad 2 \quad 2 \quad 2 \quad 0$

\section{Figure 3}

Prediction of carcinoma based on the mRNA expression levels of TARBP2, IGF2, and/or H19. The Kaplan-Meier curves separate the patients according to the expression levels of the molecular predictors TRBP2, IGF2, and/or H19. The 45 clinical cases were divided in two groups with high or low expression levels of TARBP2, IGF2, or H19 according to their median

adenomas in our cohort (Özata et al. 2011), we focused on miR-195 and miR-497. These miRNAs belong to the same miRNA cluster and show an inverse expression pattern in comparison with TARBP2 and DICER expression levels (Fig. 5B). Noteworthy, the four carcinomas with TARBP2 copy number gain and low TARBP2 expression exhibited high expression of miR-195 and miR-497. The same cases also presented low levels of DICER (Fig. 5C). These observations prompted us to investigate the role of $m i R-195$ and $m i R-497$ as potential regulators of TARBP2 and/or DICER.

To confirm whether TARBP2 and DICER were biological targets of miR-195 and miR-497 in adrenocortical tumors, we transfected NCI-H295R cells with miRNA mimics (pre-miR-195 and/or pre-miR-497). We observed
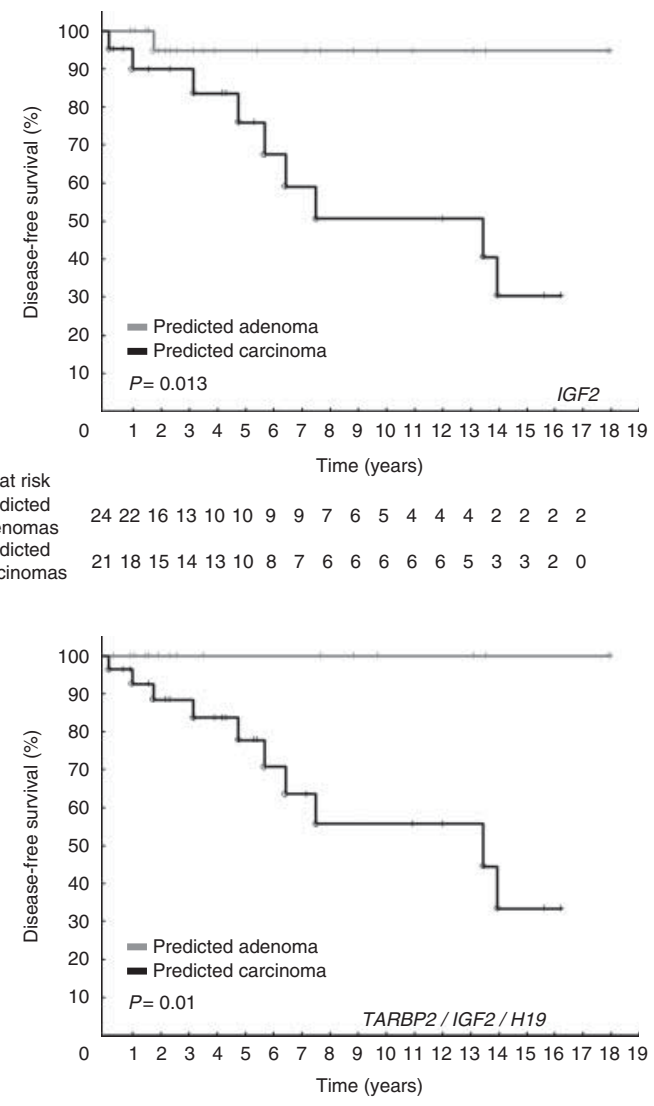

No at risk

$\begin{array}{lllllllllllllllllll}\text { Predicted } & 17 & 15 & 10 & 8 & 7 & 7 & 7 & 7 & 6 & 5 & 4 & 4 & 4 & 4 & 2 & 2 & 2 & 2\end{array}$

adenomas

Predicted

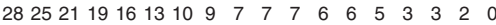

expression levels measured by RT-qPCR. A case was predicted as carcinoma if the expression level was $>0.00012$ for TARBP2, $>0.00025$ for IGF2, $<0.0019$ for $H 19$, or $>-0.0013$ for combination of the three genes. The curves of each group were compared using log-rank test and $P<0.05$ was considered significant.

a significant reduction of TARBP2 and DICER mRNA and protein expression levels in the cells over-expressing miR-195 or miR-497 compared with the cells transfected with pre-miR-negative control. miR-497 had a stronger repressive effect on both TARBP2 and DICER, and the combined over-expression of the two miRNAs showed a synergic effect on posttranscriptional regulation (Fig. 5D).

Next, we adopted the Ago2-immunoprecipitation approach to determine whether TARBP2 and DICER are direct targets of $m i R-195$ and/or $m i R-497$. Previous studies have shown that Ago complexes can stably associate with miRNA targets (Beitzinger et al. 2007, Karginov et al. 2007). Thus, we immunoprecipitated Ago2 complexes in NCI-H295R cells after induced over-expression of miR-195 or miR-497 and measured the abundance of the

Published by Bioscientifica Ltd 

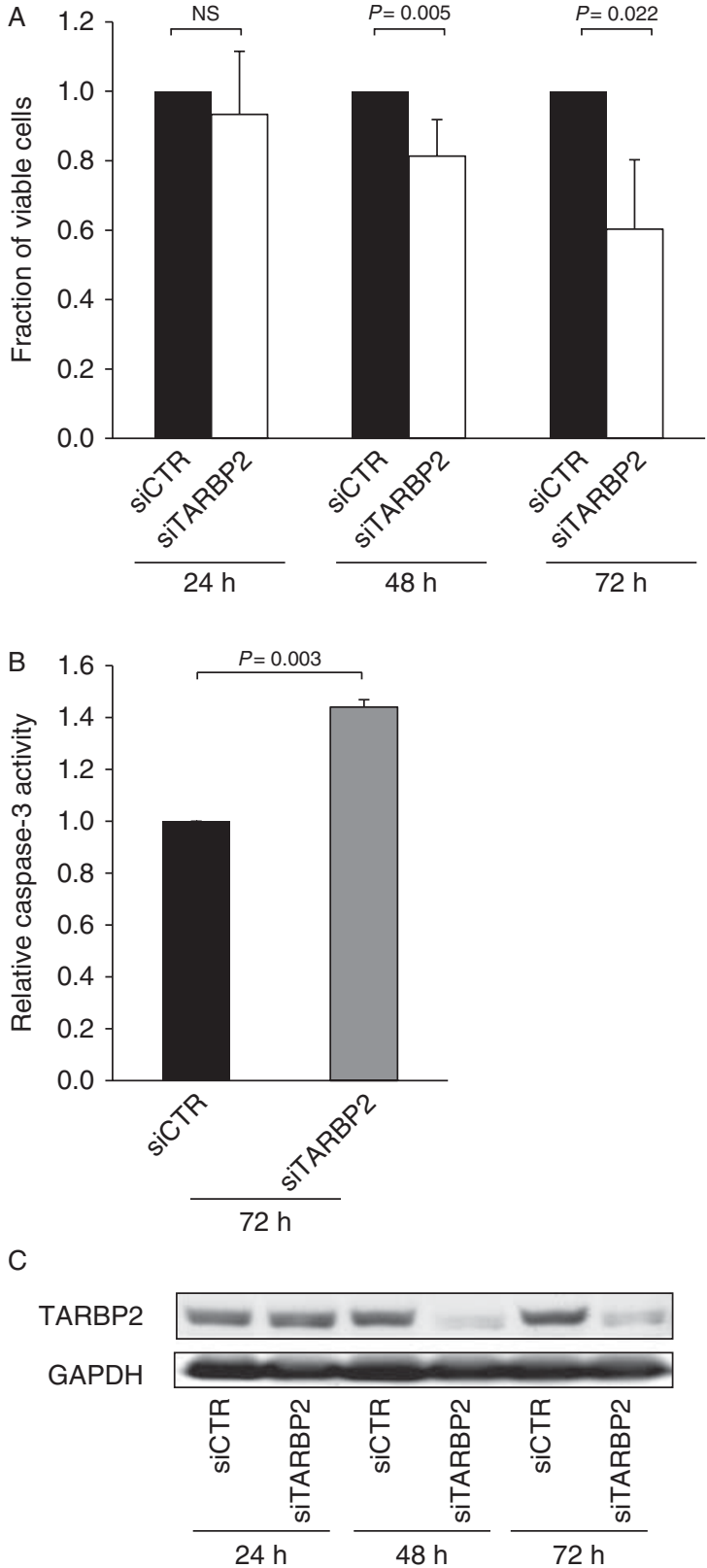

Figure 4

Silencing of TARBP2 in NCI-H295R cell line affects cell viability and apoptosis. (A) Histogram showing fractions of viable cells measured by WST-1 colorimetric assay in NCl-H295R cells transfected with siTARBP2 or siCTR at different time points (24, 48, and $72 \mathrm{~h}$ ). (B) Histogram illustrating the increase of cell death evaluated by caspase-3/CPP32 colorimetric assay in NCl-H295R cells transfected with siTARBP2 when compared with siCTR-transfected cells. Error bars represent s.D. of the mean of three independent experiments. Paired $t$-test was used to determine the differences between groups and $P<0.05$ were considered significant. (C) A representative western blot showing TARBP2 levels at 24, 48, and $72 \mathrm{~h}$ after transfection with siTARBP2 or siCTR. Incubation with a GAPDH antibody was used as a loading control. co-immunoprecipitated TARBP2 and DICER mRNAs by RT-qPCR. We observed a significant enrichment of endogenous mRNAs for both genes in cells over-expressing miR-497 $(P<0.05)$. TARBP2 mRNA was also strongly enriched in the immunoprecipitates of miR-195 over-expressing cells $(P<0.05)$ while for DICER mRNA the enrichment did not show any statistical significance (Fig. 5E).

\section{Discussion}

We report dysregulation of miRNA machinery components in adrenocortical tumors and the potential role of TARBP2 as molecular biomarker for ACC classification. In addition, we show the mechanisms of TARBP2 regulation and the functional consequences of TARBP2 deregulation in ACC cells.

\section{Over-expression of TARBP2, DICER, and DROSHA in ACCs}

We show that TARBP2, DICER, and DROSHA are significantly over-expressed in ACC when compared with adenomas and adrenal cortices. The expression pattern was validated in publicly available data sets. Disruption of miRNA machinery has been previously associated with tumorigenesis in several cancer types. In line with our findings, over-expression of TARBP2 and DICER was observed in prostate cancer (Fu et al. 2010). DICER overexpression was also reported in cutaneous melanomas (Ma et al. 2011, Sand et al. 2011) and was associated with aggressiveness in lung adenocarcinoma (Chiosea et al. 2007) and poor survival in colorectal cancer (Faber et al. 2011). Higher expression of DROSHA was found in cervical squamous cell carcinomas (Muralidhar et al. 2007) and epithelial skin cancers (Sand et al. 2010). Its over-expression was associated with poor prognosis in esophageal cancer (Sugito et al. 2006). On the contrary, reduced expression of miRNA-processing factors has also been observed in several tumor types. Decreased expression of TARBP2 was reported in colorectal and gastric cancers presenting microsatellite instability (Melo et al. 2009). Low expression of DROSHA and DICER was associated with decreased survival in ovarian cancer (Merritt et al. 2008). Decreased mRNA level of DICER was observed in basal cell carcinomas (Sand et al. 2010) and was also associated with poor prognosis in non-small-cell lung cancer (Karube et al. 2005). Together, variation of TARBP2, DICER, and DROSHA expression levels among different tumor types suggests that deregulation of miRNA-processing factors can be dependent on cellular context and imply their possible dual role as tumor

Published by Bioscientifica Ltd. 
A

miR-195 (position 263-269 of TARBP2 $33^{\prime}$ UTR)

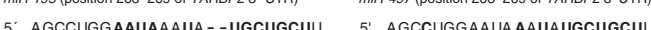

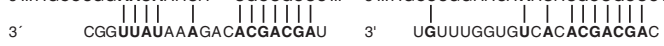

miR-195 (position 2490-2496 of DICER $3^{\prime}$ UTR) 5... UUAUGAACGCUUUUGUGCUGCUG 3. CGGUUAUAAAGACACGACGAU

miR-195 (position 2971-2977 of DICER $3^{\prime}$ UTR) 5.... AAUGUGGUUUGGCCUUGCUGCUU 3. CGgUUAUAAAGACACGACGAU

miR-497 (position 2490-2496 of DICER 3' UTR) 5.... UUAUGAACGCUUUUGUGGUGCUG 3. I I I I I I I I I I I I I

miR-497 (position 2971-2977 of DICER $3^{\prime}$ UTR) 5... AAUGUGGUUUGGCCUUGCUGCUU 3. UGUUUGGUGUCACACGACGAC
B

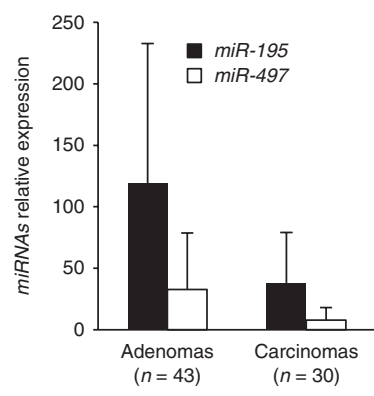



C
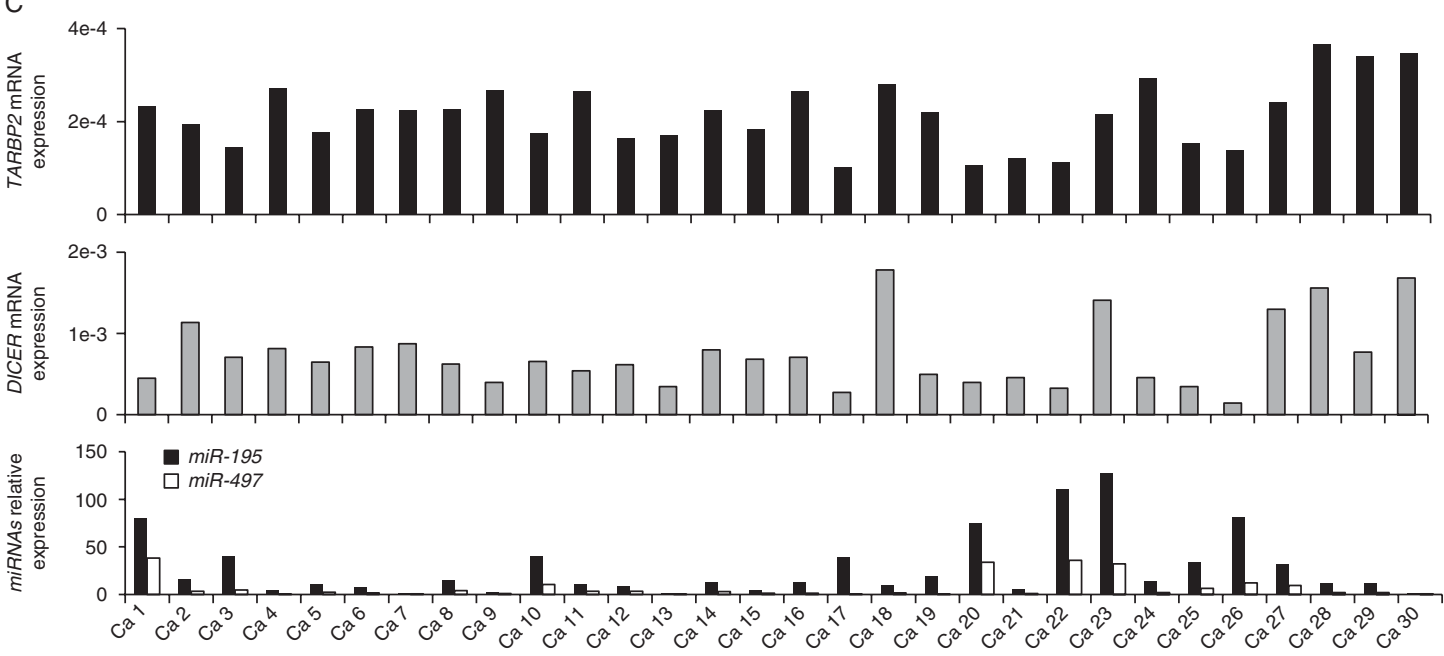

D
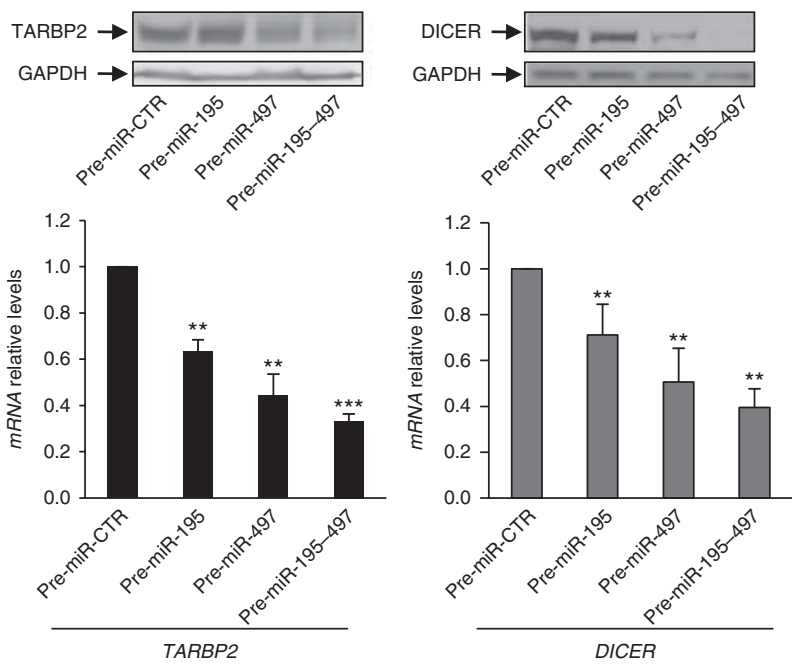

$E$

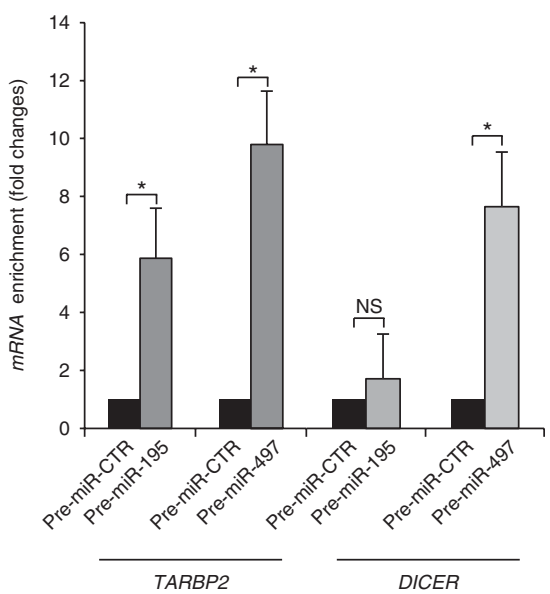

Figure 5

miR-195 and miR-497 target TARBP2 and DICER. (A) Schematic presentation of miR-195 and miR-497 predicted target sites identified in the TARBP2 and DICER 3'-UTRs by TargetScan 5.2. (B) miR-195/miR-497 and TARBP2IDICER mRNA relative expression levels in adrenocortical carcinomas $(n=30)$ in comparison to adenomas $(n=43)$ assessed by RT-qPCR. The two miRNAs show an inverse pattern of expression compared with TARBP2 and DICER. (C) Comparison between miR-195/miR-497 and TARBP2/DICER mRNA expression levels in adrenocortical carcinoma cases measured by RT-qPCR. (D) Transfection of pre-miR-195 and/or pre-miR-497 in NCI-H295R cell line represses mRNA and protein expression of TARBP2 and DICER when

http://erc.endocrinology-journals.org DOI: 10.1530/ERC-13-0098
(C) 2013 The authors Printed in Great Britain compared with pre-miR-CTR. (E) NCl-H295R cells were transfected with pre-miR-CTR, pre-miR-195, or pre-miR-497. The levels of Ago2-associated $T A R B P 2$ and DICER mRNAs were measured by RT-qPCR relative to miR-483-3p. The mRNA enrichment of TARBP2 or DICER in each anti-Ago2 IP sample was normalized to the corresponding input sample. The results are shown as fold change in comparison to the negative control and the error bars represent s.D. of the mean of three independent experiments. Differences in expression levels between groups were evaluated using paired $t$-test and $P<0.05$ was considered significant. ${ }^{*} P<0.05 ; * * P<0.01$; $* * * P<0.001 ; \mathrm{NS}$, not significant. 
suppressors or oncogenes in human cancers. Despite that we have not investigated whether deregulation of miRNA machinery genes affects the miRNA-processing efficiency in ACC cells, these effects have been demonstrated for TARBP2 and DICER in colorectal and breast cancer cells respectively (Melo et al. 2009, 2011, Martello et al. 2010).

Interestingly, we observed that TARBP2 was localized both in the cytoplasm and nucleus of tumor cells, whereas its expression was mainly found in the cytoplasm of nontumor cells. In line with our findings, RNAi pathway components (including DICER, TARBP2, AGO1, and AGO2) have been observed in the nuclear compartment of human cells (Haussecker \& Proudfoot 2005, Kim et al. 2006, Ahlenstiel et al. 2012). These observations suggest that TARBP2 may involve in nuclear RNAi on transcriptional silencing or other unknown function(s). Further analyses are warranted to investigate the potential nuclear role of TARBP2 and its implication in the pathogenesis of adrenocortical tumors.

\section{TARBP2 as molecular predictor of carcinoma and functional role in ACC cells}

Discrimination between localized ACCs and adenomas is challenging. To overcome these clinical limitations, the identification of novel molecular biomarkers is certainly needed. In our study, we show that TARBP2 is a strong predictor of carcinoma and can reliably classify ACC in a cohort of non-metastatic adrenocortical tumors.

Consistent with the over-expression observed in ACC, we also demonstrated that inhibition of TARBP2 expression could affect cell growth and apoptosis in the NCI-H295R cells. In line with these results, previous studies demonstrated that TARBP2 promotes cell growth and transformation in vitro and can induce tumor formation in mice (Benkirane et al. 1997, Lee et al. 2004). These findings suggest a possible oncogenic function of TARBP2 in ACC carcinogenesis and imply the potential use of TARBP2 as a novel therapeutic target in ACC.

\section{Regulatory mechanisms of TARBP2 over-expression in ACC}

Despite several studies showing alteration of miRNA machinery factors in different tumor types, the molecular mechanisms that regulate their expression are not fully understood. Given the over-expression and the potential oncogenic role of TARBP2 in ACC, we sought to investigate possible molecular mechanisms involved in the regulation of TARBP2 expression. TARBP2 gene mutations causing a loss of TARBP protein expression have been previously shown in colorectal and gastric cancers (Melo et al. 2009). However, in our study, the mutational analysis revealed the presence of only wildtype sequences for the TARBP2 gene in all the ACC cases analyzed, implying that genomic DNA mutations are probably not involved in the deregulation of TARBP2 in ACC. On the other hand, we found TARBP2 gene copy number gain in $57 \%(16 / 28)$ of the carcinomas, suggesting that copy number gain of TARBP2 gene may be, at least partially, responsible for its over-expression in ACC.

In addition, we propose a miRNA-mediated regulation of TARBP2 expression in ACC. While there is no evidence in the literature of miRNAs affecting TARBP2 expression, let-7 and miR-103/-107 family are known to regulate expression of DICER (Forman et al. 2008, Martello et al. 2010). Here, we demonstrate that mature miR-195 and miR-497 can directly regulate TARBP2 and DICER expression in ACC. Downregulation of miR-195 and/or miR-497 has been observed in several tumor types, including ACC (Soon et al. 2009, Özata et al. 2011, Patterson et al. 2011, Schmitz et al. 2011), liver (Xu et al. 2009), bladder (Han et al. 2011), breast (Li et al. 2011), and peritoneal carcinoma (Flavin et al. 2009). Reduced expression of miR-195 is also correlated with lymph node metastasis and poor prognosis in colorectal cancer (Wang et al. 2011). In line with the expression pattern, we previously showed that over-expression of miR-195 and miR-497 can inhibit cell growth with concomitant increase of apoptosis in NCI-H295R ACC cells (Özata et al. 2011). Together, it is intriguing to speculate that the phenotypic effect observed in ACC cell line upon alteration of miR-195 and miR-497 expression may be mediated through TARBP2 and DICER downregulation.

In summary, we report frequent over-expression of TARBP2 in ACC and we found that TARBP2 mRNA expression level is a useful predictor of ACC and able to discriminate adenomas from carcinomas. In addition, we revealed the potential oncogenic role of TARBP2 and mechanisms of its over-expression in ACC.

Supplementary data

This is linked to the online version of the paper at http://dx.doi.org/10.1530/ ERC-13-0098.

\section{Declaration of interest}

The authors declare that there is no conflict of interest that could be perceived as prejudicing the impartiality of the research reported.

Published by Bioscientifica Ltd. 


\section{Funding}

This work was supported by the Swedish Research Council (523-2009-3517 and 521-2010-3518), the Áke Olsson's Foundation for Haematological Research, the Cancer Research Funds of Radiumhemmet, the Axel and Signe Lagerman's Donation Foundation, the Swedish Cancer Society, Karolinska Institutet, and Stockholm County Council.

\section{Author contribution statement}

$S$ Caramuta and W-O Lui conceived and designed the experiments; S Caramuta and L Lee developed the methodology; S Caramuta, L Lee, D M Özata, P Akçakaya, and H Xie performed the experiments; S Caramuta, L Lee, D M Özata, P Akçakaya, H Xie, A Höög, and W-O Lui analyzed and interpreted the data; S Caramuta, L Lee, D M Özata, P Akçakaya, H Xie, A Höög, J Zedenius, M Bäckdahl, C Larsson, and W-O Lui contributed to write and/or revise the manuscript; S Caramuta, L Lee, J Zedenius, M Bäckdahl, C Larsson, and W-O Lui contributed to administrative, technical, or material support; S Caramuta and W-O Lui supervised the study.

\section{Acknowledgements}

The authors thank Ms Lisa Ånfalk for her admirable help in collecting the tumor samples and the members of the Medical Genetics group for their help and valuable suggestions. We also thank Dr Daniela Witten (Department of Biostatistics, University of Washington) for statistical advice.

\section{References}

Ahlenstiel CL, Lim HG, Cooper DA, Ishida T, Kelleher AD \& Suzuki K 2012 Direct evidence of nuclear Argonaute distribution during transcriptional silencing links the actin cytoskeleton to nuclear RNAi machinery in human cells. Nucleic Acids Research 40 1579-1595. (doi:10.1093/nar/ gkr891)

Allolio B \& Fassnacht M 2006 Clinical review: adrenocortical carcinoma: clinical update. Journal of Clinical Endocrinology and Metabolism 91 2027-2037. (doi:10.1210/jc.2005-2639)

Beitzinger M, Peters L, Zhu JY, Kremmer E \& Meister G 2007 Identification of human microRNA targets from isolated argonaute protein complexes. RNA Biology 4 76-84. (doi:10.4161/rna.4.2.4640)

Benkirane M, Neuveut C, Chun RF, Smith SM, Samuel CE, Gatignol A \& Jeang KT 1997 Oncogenic potential of TAR RNA binding protein TRBP and its regulatory interaction with RNA-dependent protein kinase PKR. EMBO Journal 16 611-624. (doi:10.1093/emboj/16.3.611)

Bertherat J, Groussin L \& Bertagna X 2006 Mechanisms of disease: adrenocortical tumors - molecular advances and clinical perspectives. Nature Clinical Practice. Endocrinology \& Metabolism 2 632-641. (doi:10.1038/ncpendmet0321)

Chendrimada TP, Gregory RI, Kumaraswamy E, Norman J, Cooch N, Nishikura K \& Shiekhattar R 2005 TRBP recruits the Dicer complex to Ago2 for microRNA processing and gene silencing. Nature $\mathbf{4 3 6} 740-744$. (doi:10.1038/nature03868)

Chiosea S, Jelezcova E, Chandran U, Luo J, Mantha G, Sobol RW \& Dacic S 2007 Overexpression of Dicer in precursor lesions of lung adenocarcinoma. Cancer Research 67 2345-2350. (doi:10.1158/0008-5472.CAN06-3533)

DeLellis RA, Lloyd RV, Heitz PU \& Eng C 2004 Tumors of the adrenal gland. In World Health Organization Classification of Tumors. Pathology and Genetics of Endocrine Organs, 135-146. Lyon, France: IARC Press.

Faber C, Horst D, Hlubek F \& Kirchner T 2011 Overexpression of Dicer predicts poor survival in colorectal cancer. European Journal of Cancer 47 1414-1419. (doi:10.1016/j.ejca.2011.01.006)
Flavin RJ, Smyth PC, Laios A, O'Toole SA, Barrett C, Finn SP, Russell S, Ring M, Denning KM, Li J et al. 2009 Potentially important microRNA cluster on chromosome $17 \mathrm{p} 13.1$ in primary peritoneal carcinoma. Modern Pathology 22 197-205. (doi:10.1038/modpathol.2008.135)

Forman JJ, Legesse-Miller A \& Coller HA 2008 A search for conserved sequences in coding regions reveals that the let-7 microRNA targets Dicer within its coding sequence. PNAS 105 14879-14884. (doi:10.1073/pnas.0803230105)

de Fraipont F, El Atifi M, Cherradi N, Le Moigne G, Defaye G, Houlgatte R, Bertherat J, Bertagna X, Plouin PF, Baudin E et al. 2005 Gene expression profiling of human adrenocortical tumors using complementary deoxyribonucleic acid microarrays identifies several candidate genes as markers of malignancy. Journal of Clinical Endocrinology and Metabolism 90 1819-1829. (doi:10.1210/jc.2004-1075)

Fu X, Xue C, Huang Y, Xie Y \& Li Y 2010 The activity and expression of microRNAs in prostate cancers. Molecular BioSystems 6 2561-2572. (doi:10.1039/c0mb00100g)

Gao ZH, Suppola S, Liu J, Heikkila P, Janne J \& Voutilainen R 2002 Association of $\mathrm{H} 19$ promoter methylation with the expression of H19 and IGF-II genes in adrenocortical tumors. Journal of Clinical Endocrinology and Metabolism 87 1170-1176. (doi:10.1210/jc.87.3.1170)

Gicquel C, Bertagna X, Schneid H, Francillard-Leblond M, Luton JP, Girard F \& Le Bouc Y 1994 Rearrangements at the 11p15 locus and overexpression of insulin-like growth factor-II gene in sporadic adrenocortical tumors. Journal of Clinical Endocrinology and Metabolism 78 1444-1453. (doi:10.1210/jc.78.6.1444)

Gicquel C, Bertagna X, Gaston V, Coste J, Louvel A, Baudin E, Bertherat J, Chapuis Y, Duclos JM, Schlumberger M et al. 2001 Molecular markers and long-term recurrences in a large cohort of patients with sporadic adrenocortical tumors. Cancer Research 61 6762-6767.

Giordano TJ, Kuick R, Else T, Gauger PG, Vinco M, Bauersfeld J, Sanders D, Thomas DG, Doherty G \& Hammer G 2009 Molecular classification and prognostication of adrenocortical tumors by transcriptome profiling. Clinical Cancer Research 15 668-676. (doi:10.1158/1078-0432.CCR-081067)

Hammarstedt L, Muth A, Wangberg B, Bjorneld L, Sigurjonsdottir HA, Gotherstrom G, Almqvist E, Widell H, Carlsson S, Ander S et al. 2010 Adrenal lesion frequency: a prospective, cross-sectional CT study in a defined region, including systematic re-evaluation. Acta Radiologica $\mathbf{5 1}$ 1149-1156. (doi:10.3109/02841851.2010.516016)

Han Y, Chen J, Zhao X, Liang C, Wang Y, Sun L, Jiang Z, Zhang Z, Yang R, Li $Z$ et al. 2011 MicroRNA expression signatures of bladder cancer revealed by deep sequencing. PLoS ONE 6 e18286. (doi:10.1371/ journal.pone.0018286)

Haussecker D \& Proudfoot NJ 2005 Dicer-dependent turnover of intergenic transcripts from the human beta-globin gene cluster. Molecular and Cellular Biology 25 9724-9733. (doi:10.1128/MCB.25.21.9724-9733. 2005)

Ilvesmaki V, Kahri AI, Miettinen PJ \& Voutilainen R 1993 Insulin-like growth factors (IGFs) and their receptors in adrenal tumors: high IGF-II expression in functional adrenocortical carcinomas. Journal of Clinical Endocrinology and Metabolism 77 852-858. (doi:10.1210/jc.77.3.852)

Karginov FV, Conaco C, Xuan Z, Schmidt BH, Parker JS, Mandel G \& Hannon GJ 2007 A biochemical approach to identifying microRNA targets. PNAS 104 19291-19296. (doi:10.1073/pnas.0709971104)

Karube Y, Tanaka H, Osada H, Tomida S, Tatematsu Y, Yanagisawa K, Yatabe Y, Takamizawa J, Miyoshi S, Mitsudomi T et al. 2005 Reduced expression of Dicer associated with poor prognosis in lung cancer patients. Cancer Science 96 111-115. (doi:10.1111/j.1349-7006.2005. 00015.x)

Kim DH, Villeneuve LM, Morris KV \& Rossi JJ 2006 Argonaute-1 directs siRNA-mediated transcriptional gene silencing in human cells. Nature Structural \& Molecular Biology 13 793-797. (doi:10.1038/nsmb1142)

Laurell C, Velazquez-Fernandez D, Lindsten K, Juhlin C, Enberg U, Geli J, Hoog A, Kjellman M, Lundeberg J, Hamberger B et al. 2009 Transcriptional profiling enables molecular classification of 
adrenocortical tumours. European Journal of Endocrinology 161 141-152. (doi:10.1530/EJE-09-0068)

Lee JY, Kim H, Ryu CH, Kim JY, Choi BH, Lim Y, Huh PW, Kim YH, Lee KH, Jun TY et al. 2004 Merlin, a tumor suppressor, interacts with transactivation-responsive RNA-binding protein and inhibits its oncogenic activity. Journal of Biological Chemistry 279 30265-30273. (doi:10.1074/jbc.M312083200)

Li D, Zhao Y, Liu C, Chen X, Qi Y, Jiang Y, Zou C, Zhang X, Liu S, Wang X et al. 2011 Analysis of MiR-195 and MiR-497 expression, regulation and role in breast cancer. Clinical Cancer Research 17 1722-1730. (doi:10.1158/1078-0432.CCR-10-1800)

Ma Z, Swede H, Cassarino D, Fleming E, Fire A \& Dadras SS 2011 Up-regulated Dicer expression in patients with cutaneous melanoma. PLOS ONE 6 e20494. (doi:10.1371/journal.pone.0020494)

Martello G, Rosato A, Ferrari F, Manfrin A, Cordenonsi M, Dupont S, Enzo E, Guzzardo V, Rondina M, Spruce T et al. 2010 A microRNA targeting dicer for metastasis control. Cell 141 1195-1207. (doi:10.1016/j.cell.2010.05.017)

Melo SA, Ropero S, Moutinho C, Aaltonen LA, Yamamoto H, Calin GA, Rossi S, Fernandez AF, Carneiro F, Oliveira C et al. 2009 A TARBP2 mutation in human cancer impairs microRNA processing and DICER1 function. Nature Genetics 41 365-370. (doi:10.1038/ng.317)

Melo S, Villanueva A, Moutinho C, Davalos V, Spizzo R, Ivan C, Rossi S, Setien F, Casanovas O, Simo-Riudalbas L et al. 2011 Small molecule enoxacin is a cancer-specific growth inhibitor that acts by enhancing TAR RNA-binding protein 2-mediated microRNA processing. PNAS 108 4394-4399. (doi:10.1073/pnas.1014720108)

Merritt WM, Lin YG, Han LY, Kamat AA, Spannuth WA, Schmandt R, Urbauer D, Pennacchio LA, Cheng JF, Nick AM et al. 2008 Dicer, Drosha, and outcomes in patients with ovarian cancer. New England Journal of Medicine 359 2641-2650. (doi:10.1056/NEJMoa0803785)

Muralidhar B, Goldstein LD, Ng G, Winder DM, Palmer RD, Gooding EL, Barbosa-Morais NL, Mukherjee G, Thorne NP, Roberts I et al. 2007 Global microRNA profiles in cervical squamous cell carcinoma depend on Drosha expression levels. Journal of Pathology 212 368-377. (doi:10.1002/path.2179)

Özata DM, Caramuta S, Velazquez-Fernandez D, Akcakaya P, Xie H, Höög A, Zedenius J, Backdahl M, Larsson C \& Lui WO 2011 The role of microRNA deregulation in the pathogenesis of adrenocortical carcinoma. Endocrine-Related Cancer 18 643-655. (doi:10.1530/ERC-11-0082)

Patterson EE, Holloway AK, Weng J, Fojo T \& Kebebew E 2011 MicroRNA profiling of adrenocortical tumors reveals miR-483 as a marker of malignancy. Cancer 117 1630-1639. (doi:10.1002/cncr.25724)

de Reynies A, Assie G, Rickman DS, Tissier F, Groussin L, Rene-Corail F, Dousset B, Bertagna X, Clauser E \& Bertherat J 2009 Gene expression profiling reveals a new classification of adrenocortical tumors and identifies molecular predictors of malignancy and survival. Journal of Clinical Oncology 27 1108-1115. (doi:10.1200/JCO.2008.18.5678)

Roh MS, Kwak JY, Kim SJ, Lee HW, Kwon HC, Hwang TH, Choi PJ \& Hong YS 2005 Expression of double-stranded RNA-activated protein kinase in small-size peripheral adenocarcinoma of the lung. Pathology International 55 688-693. (doi:10.1111/j.1440-1827.2005.01892.x)

Sand M, Gambichler T, Skrygan M, Sand D, Scola N, Altmeyer P \& Bechara FG 2010 Expression levels of the microRNA processing enzymes Drosha and dicer in epithelial skin cancer. Cancer Investigation 28 649-653. (doi:10.3109/07357901003630918)
Sand M, Gambichler T, Sand D, Altmeyer P, Stuecker M \& Bechara FG 2011 Immunohistochemical expression patterns of the microRNA-processing enzyme Dicer in cutaneous malignant melanomas, benign melanocytic nevi and dysplastic melanocytic nevi. European Journal of Dermatology 21 18-21.

Schmitz KJ, Helwig J, Bertram S, Sheu SY, Suttorp AC, Seggewiss J, Willscher E, Walz MK, Worm K \& Schmid KW 2011 Differential expression of microRNA-675, microRNA-139-3p and microRNA-335 in benign and malignant adrenocortical tumours. Journal of Clinical Pathology 64 529-535. (doi:10.1136/jcp.2010.085621)

Schteingart DE 2007 Adjuvant mitotane therapy of adrenal cancer - use and controversy. New England Journal of Medicine 356 2415-2418. (doi:10.1056/NEJMe078087)

Soon PS, Tacon LJ, Gill AJ, Bambach CP, Sywak MS, Campbell PR, Yeh MW, Wong SG, Clifton-Bligh RJ, Robinson BG et al. 2009 miR-195 and miR483-5p identified as predictors of poor prognosis in adrenocortical cancer. Clinical Cancer Research 15 7684-7692. (doi:10.1158/10780432.CCR-09-1587)

Stephan EA, Chung TH, Grant CS, Kim S, Von Hoff DD, Trent JM \& Demeure MJ 2008 Adrenocortical carcinoma survival rates correlated to genomic copy number variants. Molecular Cancer Therapeutics 7 425-431. (doi:10.1158/1535-7163.MCT-07-0267)

Stojadinovic A, Brennan MF, Hoos A, Omeroglu A, Leung DH, Dudas ME, Nissan A, Cordon-Cardo C \& Ghossein RA 2003 Adrenocortical adenoma and carcinoma: histopathological and molecular comparative analysis. Modern Pathology 16 742-751. (doi:10.1097/01.MP. $0000081730.72305 .81)$

Sugito N, Ishiguro H, Kuwabara Y, Kimura M, Mitsui A, Kurehara H, Ando T, Mori R, Takashima N, Ogawa R et al. 2006 RNASEN regulates cell proliferation and affects survival in esophageal cancer patients. Clinical Cancer Research 12 7322-7328. (doi:10.1158/1078-0432.CCR-06-0515)

Tombol Z, Szabo PM, Molnar V, Wiener Z, Tolgyesi G, Horanyi J, Riesz P, Reismann P, Patocs A, Liko I et al. 2009 Integrative molecular bioinformatics study of human adrenocortical tumors: microRNA, tissuespecific target prediction, and pathway analysis. Endocrine-Related Cancer 16 895-906. (doi:10.1677/ERC-09-0096)

Wang X, Wang J, Ma H, Zhang J \& Zhou X 2011 Downregulation of miR195 correlates with lymph node metastasis and poor prognosis in colorectal cancer. Medical Oncology 29 919-927. (doi:10.1007/s12032011-9880-5)

Weiss LM, Medeiros LJ \& Vickery AL, Jr 1989 Pathologic features of prognostic significance in adrenocortical carcinoma. American Journal of Surgical Pathology 13 202-206. (doi:10.1097/00000478198903000-00004)

Xie H, Zhao Y, Caramuta S, Larsson C \& Lui WO 2012 miR-205 expression promotes cell proliferation and migration of human cervical cancer cells. PLoS ONE 7 e46990. (doi:10.1371/journal.pone.0046990)

Xu T, Zhu Y, Xiong Y, Ge YY, Yun JP \& Zhuang SM 2009 MicroRNA-195 suppresses tumorigenicity and regulates G1/S transition of human hepatocellular carcinoma cells. Hepatology 50 113-121. (doi:10.1002/ hep.22919)

Yano T, Linehan M, Anglard P, Lerman MI, Daniel LN, Stein CA, Robertson CN, LaRocca R \& Zbar B 1989 Genetic changes in human adrenocortical carcinomas. Journal of the National Cancer Institute $\mathbf{8 1}$ 518-523. (doi:10.1093/jnci/81.7.518)

Received in final form 2 May 2013

Accepted 10 May 2013

Made available online as an Accepted Preprint

13 May 2013 http://erc.endocrinology-journals.org

DOI: 10.1530/ERC-13-0098 (c) 2013 The authors Printed in Great Britain
Published by Bioscientifica Ltd 